\title{
Philosophy of Economics: The Constructivist and Scientific Realist Interpretation of Macroeconomics ${ }^{1}$
}

\author{
BARTOSZ SCHEUER, MARIUSZ MAZIARZ \\ The Faculty of Economic Sciences, Wroclaw University of Economics, Komandorska 118/120, 53-345 Wroclaw, Poland \\ Email: bartosz.scheuer@ue.wroc.pl; mariusz.maziarz@ue.wroc.pl
}

\begin{abstract}
The contemporary methodological debate focuses on studying the relation between models and reality regarding idealization and resemblance. Limited attention is put on the process of model building. The study focuses its attention on the latter. The purpose of this article is twofold. First, we reconstruct the philosophical presuppositions of the participants of a cliometric debate. Second, we employ the Fleckian constructivist philosophy with the aim of offering an account of how econometric facts are constructed. Contrary to our reconstruction of the process of 'observing' macroeconomic phenomena, econometricians ground their viewpoint in the scientific-realist and neopositivist philosophies of science.
\end{abstract}

Keywords: econometrics, philosophical presuppositions, constructing observations, emerging contrary result phenomenon, constructivist methodology

\section{INTRODUCTION}

The philosophy of economics literature focuses mostly on analysing the relation between a model and reality (e.g. Hands 2011; Mäki 2008, 2011; Niiniluoto 2011). Hitherto, a little emphasis was put on the process of model construction. Notable exceptions are Harper's (1998a, 1998b) anthropological study of everyday work routine at IMF and Boldyrev and Ushakov's (2016) analysis of the constructive mechanisms in the general equilibrium theory. Econometrics, as a mean of observation of economic reality, delivers models that are believed to represent their target system. However, contrary to the widespread belief, data-driven models generate macroeconomic observations which are fallible and conditioned by quantitative techniques.

The purpose of the article is twofold. On the one hand, we aim at reconstructing philosophical presuppositions held by macroeconometricians. On the other, we use the Fleckian constructivist philosophy to show how methodological decisions shape modelling results. The study focuses on the cliometric literature on the debt-to-GDP 90\%-threshold hypothesis

1 The research was partially supported by the National Science Centre, Poland, under Grant No. 2015/19/N/ HS1/01066. Mariusz Maziarz acknowledges Ph. D. scholarship from the National Science Centre, Poland, under Grant No. 2018/28/T/HS1/00007. 
due to the relative simplicity of quantitative techniques and its soundness in the methodological debate (Krugman 2013; Maziarz 2017). In Section 2, employing the method of inference to the best explanation (IBE), we reconstruct the following presuppositions held by its participants: the received-view belief that (1) observations are distinct from theories, (2) the semantic commitment of scientific realism, (3) the causal theory of reference, and (4) the viewpoint according to which the subsequent theories converge on. Section 3 offers a description of the process of generating macroeconomic observations. Employing the distinction between active and passive elements of knowledge coined by Fleck (1979), we show how quantitative techniques employed by researchers generate econometric 'observations'.

\section{THE PHILOSOPHICAL PRESUPPOSITIONS}

The contemporary mainstream philosophy of economics is constituted by a mix of neopositivist and scientific realist presuppositions. First, those whose philosophical investigations aim at criticizing the mainstream methodology choose either logical positivism (e.g. McCloskey 1998) or a mix of the former and scientific realism (e.g. Lawson 2006) to be a whipping boy. Second, the most notable examples of the philosophy-of-economics literature are either scientific-realistically flavoured (e.g. Mäki 1992; Cartwright 1994; Hoover 1997) or grounded in logical positivism (Blaug 1992). ${ }^{2}$ Below, the four philosophical presuppositions held by the participants of the cliometric discourse focused on the $90 \%$ debt threshold are reconstructed.

\section{Theory-observation distinction}

One of the central tenets of the logical positivist viewpoint on science is distinguishing between theory and observation or, to put it differently, observational language and theoretical language (Carnap 1975). In line with the traditional reconstruction of the received view, logical positivists emphasized that observations, despite being also fallible, are more confident and less prone to error than theories. This epistemic stance can be traced back to the Humean distinction between 'empirical matters of fact' and synthetic truths of reason (Norris 2006; Carnap 1966: 16).

The viewpoint according to which the neopositivist distinction between theory (laws) and observational facts is incorporated into the mainstream philosophy of economics is supported by McCloskey's (1998: 226-228) reconstruction thereof and Blaug's (1992) mix of neopositivism and falsificationism being centered around the latter. The author of The Methodology of Economics. Or, How Economists Explain seems to have incorporated the distinction, especially considering his emphasis on the role of facts that 'test' scientific theories. For instance, Blaug (1992: 67) wrote that evidence (i.e. observational facts) falsified the Malthusian theory of population. In a similar vein, the Dutch-born British economist (Blaug 1992: 149) depicted the process of theory testing as producing hypotheses (refutable predictions) and confronting them with reality.

The belief that observational facts are somehow less prone to falsification (or, to use the neopositivist term, disconfirmation) correlates with how the cliometricians received Herndon, Ash and Pollin's (2014) criticism. The emphasis of the commentators was put on the rightness and wrongness of the averaging schemes, and little attention was put on the issue of data

2 Mark Blaug, in spite of paying lip-service to the Popperian falsificationism, reads his epistemological work in line with Agassi’s simplifying reconstruction (McCloskey 1989; Boland 2016). 
exclusion (cf. Maziarz 2017: 3). Virtually no attention was put on the issue of relevance of the data sample that was employed by Reinhart and Rogoff (2010) and subsequently by Herndon, Ash and Pollin to producing their estimates of average GDP growth.

Additionally, most of the commentators assumed the observations (i.e. the data gathered by Reinhart and Rogoff (2010)) to be constant and focused on considering the other two 'flaws' raised by Herndon, Ash and Pollin (2014). For example, Pescatori, Sandri and Simon (2014) summarized the controversy as follows: 'the findings of R \& R (2010) have been recently challenged by Herndon, Ash and Pollin (2013), which show that the threshold effect seems to vanish after correcting for a coding error and using a different weighting of the data' (p. 5; our emphasis). In the above-quoted passage, the team of cliometricians working for IMF took the observations for granted (omitting the issue of excluding post-WWII data raised by Herndon, Ash, and Pollin) and focused on the other two methodological issues, i.e. calculating the averaging scheme and the spreadsheet error.

\section{Semantic commitment}

Scientific realism accepts the three dimensions: (1) semantic, (2) ontic and (3) epistemological. According to the former dimension, statements drawn from theories are made true or false by how the (economic) world is. In other words, scientific realists support (a handful of versions of) the definition of truth formalized by Alfred Tarski (1944) and interpreted in the correspondence way by Karl Popper (2002). For instance, Mäki (2009: 58) indicated that ' $[\mathrm{m}]$ odels are representatives of some target systems: they are surrogate systems that stand for their targets and are examined in place of their targets' and the models are true or false because of its relata: 'truth is independent of our ways and chances of finding about it. Pragmatists of various sorts contain the negation of this realist idea' (Mäki 2008: 435). The relation of correspondence is currently understood as depicting of or corresponding to only essential aspects of reality in line with Nowak's (1980) method of isolation what Niiniluoto (2002) called 'essesimilitude', corresponding to essences or ontic bases of the economic reality.

Adopting the semantic commitment of scientific realism leads to accepting the stance according to which only one of two seemingly contrary relations can be true. The reading in line with the semantic commitment of, for example, Reinhart and Rogoff's (2010) result states that there is the threshold above which public debt hampers economic development in a higher degree than below thereof. The criticism published by Herndon, Ash and Pollin (2014) promoted (or, at least, was interpreted as a result that promoted) the viewpoint according to which high levels of public debt do not hamper economic growth.

All econometricians taking part in the discourse agreed that the two results constituting the controversy are contradictory (Reinhart and Rogoff (2010): $T=90 \%$; Herndon et al. (2014): $T=\varnothing$ ). For instance, Grimpson (2014) (mistakenly identifying the reason of the contradictoriness with the spreadsheet error) stated that 'Growth in a Time of Debt which had a major impact on global economic policy and which was subsequently shown by Herndon, Ash, and Pollin to have been based on an incorrect Excel spreadsheet. The errors in the spreadsheet were such as to invalidate the conclusions of the paper' (Grimpson 2014: 39; our emphasis). Accepting the semantic dimension of scientific realism can also be reconstructed from the replication study. Herndon, Ash and Pollin (2014) claimed in the abstract section that their 'overall evidence refutes RR's claim that public debt/GDP ratios above $90 \%$ consistently reduce a country's GDP growth' (p. 1). A similar argument was put forth also by, among others, Lee et al. (2014: 2). 


\section{The causal theory of reference}

The causal theory of reference enabled defending the realist stance because it states that a referent exists independently of its description(s). As Putnam (1984) puts it, different theories refer to the same entities in different ways. Referents are the same despite the description change. Reinhart and Rogoff (2010), to calculate the average pace of economic growth, employed the weighted averaging scheme (Maziarz 2017):

Equation 1. The average pace of economic growth calculated by Reinhart and Rogoff (2010):

$$
\hat{B}_{1}=\frac{\frac{\sum \frac{z_{1}}{t=1} G D P_{t 1}}{z_{1}}+\frac{\sum \frac{z_{2}}{t=1} G D P_{t 2}}{z_{2}}+\ldots+\frac{\sum \frac{z_{n}}{t=1} G D P_{t n}}{z_{n}}}{n}
$$

$\hat{B}_{t}$ is the average GDP growth of the $\mathrm{i}$-th basket; $G D P_{t X}$ is the GDP growth in the year $\mathrm{t}$ of the country X; $z_{n}$ is the number of periods of the $\mathrm{n}$-th country included in a considered basket; $n$ is the number of countries in a considered basket.

In contrary, Herndon, Ash and Pollin (2014) employed the unweighted averaging scheme leading to diverging estimates.

Equation 2. The averaging scheme employed by Herndon, Ash and Pollin (2014):

$$
\hat{B}_{\mathrm{\imath}}=\frac{\sum_{x=1}^{n} \sum_{t=1}^{z} G D P_{t x}}{n^{*} z} .
$$

Accepting the causal theory of reference leads to the following reconstruction of the controversy: an independently existing average pace of economic development caused Reinhart and Rogoff (2010) to describe it by the weighted averaging scheme and Herndon, Ash and Pollin (2014) by the unweighted one, then both these descriptions refer to the same, mind-independent ${ }^{3}$ entity and (hence) are contrary.

Dafoe (2014) indicated that most of the popular-press comments focused on the spreadsheet error because it was a 'perfect made-for-TV mistake' (p. 1). The commentators that publish in the popular press seem to implicitly assume without further considerations that averaging schemes and post-WWII data exclusion did not influence the results in a significant way because both averaging schemes are aimed at delivering an estimate of (the same) GDP growth. Even an enlightened analysis of Reiss (2014), who restrained from playing the judgmental role on the controversy, is committed to the realism-driven fallacy of assuming that the two analyses are contradictory by indicating that the choice between them is to be made.

\section{Convergent realism}

The epistemological commitment is the belief that most developed theories are true or close to true (verisimilar). Convergent realism is listed by, for instance, Leplin (1984, pp. 1-2) as

3 The existence of the realism/antirealism debate should be noted here. However, justification of these two stances is not relevant for the purpose of the article. 
one of the philosophical presuppositions of scientific realism. Science is believed to develop over time so that subsequent theories are closer to truth and observing a sequence of several next theories leads to the conclusion that they converge at the correspondingly defined truth (Ketner, Putnam 1992; Mäki 2011). It was formulated as a response to the pessimistic induction argument against scientific realism. The critics of Reinhart and Rogoff (2010) analysis seem to aprioristically (i.e. without a deeper, methodologically-informed consideration) assume that among the two divergent cliometric techniques, the second, chronologically latter one, is better than the former. For instance, in the politically-driven text The Excel Depression That Changed History, Paul Krugman listed the three methodological issues raised by Herndon, Ash and Pollin (2014) and argued that correcting them leads to contradicting the $90 \%$-debt hypothesis (Krugman 2013; Clemens 2015).

\section{The construction of econometric facts}

In this Section, we employ the Fleckian philosophy of science with the aim of depicting the process of constructing macroeconomic observations using econometric modelling. Section 3.1. discusses the construction of the debt-threshold hypothesis regarding the theory of thought styles with a view to offering an abstract account of the construction of econometric observations. Section 3.2. focuses on the process of empirical-hypothesis confirmation.

\section{The construction of econometric observations}

According to the Fleckian perspective, 'objective reality' is not independent of cognition and is not discovered. In contrary, it is a construction specific to a particular thought style (Fleck 1979: 98). There is nothing 'independent' and 'objective' in those 'facts' because every 'fact must be expressed in the style of the thought collective' (1979: 102) and only 'such a stylized solution $\langle\ldots\rangle$ is called truth' (Fleck 1979: 100). Regarding the cliometric literature on the $90 \%$-threshold hypothesis, two thought styles characterized by different preference regarding methods can be distinguished. Considering Maziarz's (2017: 216) observation that the difference is caused mostly (up to $74 \%$, to be strict) by choice between the two averaging schemes, the controversy clearly instantiates Fleck's observation that what is regarded as true is style-determined.

Two more elements are essential in the constructivist reconstruction of the process of macroeconometric modelling. First, according to the constructivist philosophy of science, facts are not determined by 'reality' but by style-determined presuppositions and previously accepted theories (Fleck 1979: 102). In other words, the whole knowledge is holistic in its nature and understandable only within the particular style. Second, this endless process of the creation and re-creation of facts is a consequence of changes in meanings of and relationships between concepts present in that style. Thus 'we can define scientific fact as a thought-stylized conceptual relation which can be investigated from history and that of psychology, both individual and collective, but which cannot be substantively reconstructed in toto simply from these points of view. This expresses the inseparable relation between active and passive parts of knowledge as well as the phenomenon that the number of both these parts of knowledge increases with the number of facts' (Fleck 1979: 83). From the perspective of an individual subject (as a member of a particular thought collective) what emerges in cognition seems to be independent of that cognition and be part of the non-discursive reality. 
To offer an account of how econometric observations are constructed, Fleck's distinction between passive and active elements of knowledge needs to be reconstructed. Active elements (definitions, basic concepts, methods perceived as valid, normative convictions, etc.) are part of collective knowledge and their presence could be explained only through the history of the particular thought style. Passive elements emerge as the results of constraints produced within the style-thinking by using those active elements. Here, active elements are cliometric techniques, definitions and data sets employed to econometric modelling. Passive elements, i.e. the divergent stances on the existence of the threshold (cf. Table 1), are determined by the active elements. The case study under consideration shows that some of the active elements differ (namely: the averaging scheme and the decision on excluding uncertain observations), but others are accepted by both thought styles what makes commensurability possible (cf. Giedymin 1986; Sady 2001).

In the case of the econometric modelling, active elements of knowledge are defined as decisions regarding methods of estimation. For instance, in the case of the cliometric research on the $90 \%$-debt hypothesis, these include choosing a data sample, a defining method of calculating average growth in subsamples, the identification thereof, etc. These choices regarding technical methods are not in fact undertaken independently by econometricians, but are predetermined by traditional ways of modelling accepted within a thought style. In the case of econometrics, the passive elements of knowledge are the results of model estimation, i.e. 'facts' seen in these models. Considering that direct observation of economy (namely: without the use of econometric methods) is impossible and therefore comparing modelling results with reality is impossible, these 'facts' are true only within a particular framework described by a set of the active elements of knowledge. Instantiating the constructivist account of econometric modelling with the case of the 90\% debt-to-GDP threshold hypothesis, the active elements are as follows: (1) defining a sample (e.g. post-war OECD countries, excluding uncertain estimates etc.), (2) choosing methods of measuring (e.g. GDP instead of GNP, the particular definition of debt, ${ }^{4}$ etc.), and finally (3) discriminating between the averaging schemes. The passive elements are the 'facts observed' using the cliometric analysis, i.e. either the existence or nonexistence of the $90 \%$ threshold.

Every scientific fact is permanently 'not finished' in developing and therefore the structure of the elements of knowledge changes regularly. The cliometric literature on the relation between debt and growth started when Reinhart and Rogoff (2010) published their analysis. Later, this result was corroborated using econometric modelling (e.g. Kumar and Woo 2010). The result was contradicted by Herndon, Ash and Pollin (2014) and several other analyses due to employing different empirical methods (cf. Maziarz 2017: 222-223). Recently, Chudik et al. (2017) argued that the threshold levels vary and are country-specific. Considering that the majority of analyses is based on the data set delivered by Reinhart and Rogoff $(2010,2009)$, the divergent results are constructed by various cliometric and econometric techniques.

\section{Confirming/disconfirming observations and hypotheses}

From the constructivist perspective, theories are self-reflexive. There is no way of falsifying/ verifying the passive elements of knowledge other than using the intercolective discourse and rational criticism that leads to accepting or modifying the active elements of knowledge. In other words, the views and presuppositions on 'facts' and 'observations' held by

\footnotetext{
4 For the discussion of how different definitions of debt influence the results, see Egert (2013).
} 
the participants of the discourse influence their approval of both research methods (active elements) and 'observation' (passive elements). If 'observation' is accepted, then research methods are also held as good. In contrary, discursive criticism of observation leads to a modification of quantitative techniques.

Additionally, what is a passive element of knowledge on a certain stage of the scientific enterprise is employed as an active element on another stage. For instance, accepting/ rejecting the threshold hypothesis is an active element of an applicable theory of economic policy-making.

Furthermore, the constructivist stance sheds light on the reception of the Reinhart-Rogoff controversy. The two different truth-values of the threshold hypothesis (Reinhart and Rogoff 2010; Herndon et al. 2014) refer not to the 'independent, objective reality' but active and passive elements of knowledge present in both thought styles and being used in the construction of those facts. First, the averaging schemes are an active element of knowledge which makes possible to construct the concept of 'average GDP growth'. The latter emerges as a passive element (and in this sense seems to be objective). From the mainstream stance, 'average GDP growth' exists independently of its descriptions thus both different average schemes employed, on the one hand, by RR and, on the other hand, by HAP refer to 'the same average GDP growth'. However, those different schemes produce two different 'average GDP growths' of which each is a passive element of its own thought style.

\section{CONCLUSIONS}

The cliometricians interested in the $90 \%$ debt-to-GDP threshold hypothesis are guided by the philosophical presuppositions of the mainstream philosophy of economics understood as a mix of logical positivism and scientific realism. First, the certitude of observations is believed to be higher than theoretical hypotheses. Second, the results of econometric modelling are interpreted as descriptions of reality. Third, concepts defined and measured differently are taken as resembling the same entities. Fourth, chronologically latter research results are accepted on the ground of the belief in the linear development of knowledge. Contrary to these philosophical presuppositions, the reconstruction of the process of constructing observations grounded in the constructivist philosophy of science highlights the conventionalist/constructivist aspect of empirical research. First, the results of empirical macroeconomic research depend on the methods employed by the cliometricians (active elements of knowledge). Second, considering that comparing constructed facts with reality by means other than by employing the active elements of knowledge is impossible, what is observed (scientific facts) is established in an intercollective discourse.

Received 20 April 2018

Accepted 7 November 2018

\section{References}

1. Bell, A.; Johnston, R.; Jones, K. 2014. "Stylised Fact or Situated Messiness? The Diverse Effects of Increasing Debt on National Economic Growth", Journal of Economic Geography 15(2): 449-472.

2. Blaug, M. 1992. The Methodology of Economics: Or, How Economists Explain. Cambridge University Press.

3. Boland, L. A. 1991. "Current Views on Economic Positivism", in Companion to Contemporary Economic Thought. Routledge, 88-104.

4. Boland, L. A. 2016. "Philosophy of Economics versus Methodology of Economics", Studia Metodologiczne 36(2016): 17-26.

5. Boldyrev, I.; Ushakov, A. 2016. "Adjusting the Model to Adjust the World: Constructive Mechanisms in Postwar General Equilibrium Theory", Journal of Economic Methodology 23(1): 38-56. 
6. Boumans, M.; Davis, J. B. 2015. Economic Methodology: Understanding Economics as a Science. Palgrave Macmillan.

7. Carnap, R. 1966. An Introduction to the Philosophy of Science. Basic Books.

8. Carnap, R. 1975. "Observation Language and Theoretical Language", in Rudolf Carnap. Logical Empiricist. Dordrecht: D. Reidel Publishing Company, 75-85.

9. Cartwright, N. 1994. Nature's Capacities and their Measurement. Cambridge: Cambridge University Press. 10. Chmielewski, A. 2003. Filozofia Poppera. Analiza krytyczna. Wrocław: Wydawnictwo Uniwersytetu Wrocławskiego.

11. Chudik, A.; Mohaddes, K.; Pesaran, M. H.; Raissi, M. 2017. "Is There a Debt-threshold Effect on Output Growth?", Review of Economics and Statistics 99(1): 135-150.

12. Clemens, M. A. 2015. "The Meaning of Failed Replications: A Review and Proposal", Journal of Economic Surveys 31(1): 326-342.

13. Dafoe, A. 2014. "Science Deserves Better: The Imperative to Share Complete Replication Files", PS: Political Science \& Politics 47(01): 60-66.

14. Egert, B. 2013. The 90\% Public Debt Threshold: The Rise and Fall of a Stylised Fact. OECD Economics Department Working Papers, No. 1055. Paris: OECD Publishing.

15. Folina, J. 2014. "Poincaré and the Invention of Convention", in Poincaré, Philosopher of Science. Springer Netherlands, 22-45.

16. Garrett, N. 2015. “Textbooks for Responsible Data Analysis in Excel”, Journal of Education for Business 90(4): 169-174.

17. Giedymin, J. 1986. "Polish Philosophy in the Inter-war Period and Ludwik Fleck's Theory of Thought-styles and Thought-collectives", in Cognition and Fact. Springer Netherlands, 179-215.

18. Glasersfeld, E. V. 1996. "Farewell to Objectivity", Systems Research 13(3): 279-286.

19. Grimson, J. 2014. "Measuring Research Impact: Not Everything That Can Be Counted Counts, and Not Everything That Counts Can Be Counted", in Bibliometrics. Use and Abuse in the Review of Research Performance, 29-41.

20. Hamilton, J. 2013. "Reinhart-Rogoff and Herndon-Ash-Pollin: A Few Further Comments", in Econbrowser. Analysis of the Current Economic Conditions and Policy. Available at: https://econbrowser.com/ archives/2013/04/reinhartrogoff_1 (cited 18.08.2017).

21. Herndon, T.; Ash, M.; Pollin, R. 2014. "Does High Public Debt Consistently Stifle Economic Growth? A Critique of Reinhart and Rogoff”, Cambridge Journal of Economics 38(2): 257-279.

22. Hoover, K. D. 1997. Econometrics and Reality. Working Paper Series 9728. Davis: Department of Economics, University of California.

23. Hutchison, T. W. 1938. The Significance and Basic Postulates of Economic Theory. London: MacMillan.

24. Ketner, K.; Putnam, H. 1992. Reasoning and the Logic of Things. Harvard: Harvard University Press.

25. Krugman, P. 2013. “The Excel Depression”, The New York Times. Available at: https://www.nytimes. com/2013/04/19/opinion/krugman-the-excel-depression.html?_r=1

26. Lawson, T. 2006. Economics and Reality. Routledge.

27. Lee, S.; Park, H.; Seo, M. H.; Shin, Y. 2014. A Contribution to the Reinhart and Rogoff Debate: Not 90 Percent But Maybe 30 Percent. Cemmap Working Paper No. CWP39/14. Centre for Microdata Methods and Practice.

28. Leplin, J. (ed.). 1984. Scientific Realism. Vol. 323. University of California Press.

29. Ludwik, F. 1979. Genesis and Development of a Scientific Fact. Chicago: University of Chicago Press.

30. Mäki, U. 1992. On the Method of Isolation in Economics. Helsinki.

31. Mäki, U. 2011. "Scientific Realism as a Challenge to Economics (and vice versa)", Journal of Economic Methodology 18(01): 1-12.

32. Maziarz, M. 2017. "The Reinhart-Rogoff Controversy as an Instance of the 'Emerging Contrary Result' Phenomenon”, Journal of Economic Methodology 24(3): 213-225.

33. McCloskey, D. 1998. The Rhetoric of Economics. London: University of Wisconsin Press.

34. McCloskey, D. N. 1989. "Why I Am No Longer a Positivist", Review of Social Economy 47(3): 225-238.

35. Niiniluoto, I. 2002. "Truthlikeness and Economic Theories", in Fact and Fiction in Economics: Models, Realism and Social Construction, ed. U. Maki. London: Cambridge University Press, 214-231.

36. Niiniluoto, I. 2012. "The Verisimilitude of Economic Models", in Economics for Real: Uskali Mäki and the Place of Truth in Economics, ed. U. Mäki. Cambridge: Cambridge University Press, 65-80. 
37. Norris, C. 2006. “The Blank and the Die: Some Dilemmas of Post-Empiricism”, International Journal of Philosophical Studies 14(2): 159-189.

38. Nowak, L. 1980. The Structure of Idealization. Towards a Systematic Reconstruction of the Marxian Idea of Science. London: Reidel.

39. Perry, G.; Serven, L.; Suescun, R. 2007. Fiscal Policy, Stabilization, and Growth: Prudence or Abstinence? Washington, DC: The World Bank.

40. Pescatori, A.; Sandri, D.; Simon, J. 2014. Debt and Growth: Is There a Magic Threshold? IMF Working Paper 14/35. Washington: International Monetary Fund.

41. Poincare, H. 2012 (1902). Science and Hypothesis. Dover: Courier Corporation.

42. Popper, K. R. 2002. The Logic of Scientific Discovery. London: Routledge.

43. Psillos, S. 2011. "Living with the Abstract: Realism and Models", Synthese 180(1): 3-17.

44. Putnam, H. 1984. "The Craving for Objectivity", New Literary History 15(2): 229-239.

45. Reinhart, C. M.; Rogoff, K. S. 2009. This Time is Different: Eight Centuries of Financial Folly. Princeton: Princeton University Press.

46. Reiss, J. 2014. "Struggling Over the Soul of Economics: Objectivity versus Expertise", in Experts and Consensus in Social Science. Springer International Publishing, 131-152.

47. Sady, W. 2001. "Ludwik Fleck-Thought Collectives and Thought Styles", Poznan Studies in the Philosophy of the Sciences and the Humanities 74: 197-206.

48. Scheuer, B. 2012. "Radical Constructivism and Methodology of Economics", Zeszyty Naukowe Wyższej Szkoły Bankowej we Wrocławiu 28: 9-18.

49. Schinckus, C. 2010. "Is Econophysics a New Discipline? The Neopositivist Argument", Physica A: Statistical Mechanics and its Applications 389(18): 3814-3821.

50. Schuchman, D. 2013. "That Reinhart and Rogoff Committed a Spreadsheet Error Completely Misses the Point", FORBES. Available at: https://www.forbes.com/sites/realspin/2013/04/18/that-reinhart-and-rogoff-committed-a-spreadsheet-error-completely-misses-the-point/\#68eaf9b837e2 (cited 18.04.2018).

51. Serrano, D. T. 2006. "A Positivist Tradition in Early Demand Theory", Journal of Economic Methodology 13(1): 25-47.

52. Tarski, A. 1944. "The Semantic Conception of Truth: And the Foundations of Semantics", Philosophy and Phenomenological Research 4(3): 341-376.

BARTOSZAS SCHEUERIS, MARIUSZAS MAZIARZAS

\title{
Ekonomikos filosofija: konstruktyvistinè ir mokslinė realistinẻ makroekonomikos interpretacija
}

\begin{abstract}
Santrauka
Šiuolaikinès metodologinès diskusijos paprastai susitelkia į modelio ir tikrovès santykio analizę idealizacijos bei panašumo fenomenų kontekste. Vis dèlto nepakankamai dėmesio skiriama pačiam modelių kūrimo procesui. Šio straipsnio autoriai kaip tik ir sutelkia savo dèmesị i minètąji procesą. Straipsnio tipas yra dvejopas. Pirma, rekonstruojamos kliometrinio ginčo dalyvių filosofinès prielaidos. Antra, siekiant paaiškinti, kaip konstruojami ekonometriniai faktai, taikoma konstruktyvistinè L. Fleko filosofija. Prieinama prie išvados, kad, priešingai nei straipsnio autoriai rekonstruoja makroekonomikos fenomenų „stebéjimo“ procesą, ekonometrijos šalininkai grindžia savo požiūrị realistine ir pozityvistine mokslo filosofijos koncepcijomis.
\end{abstract}

Raktažodžiai: ekonometrija, filosofinès prielaidos, stebejimų konstravimas, atsirandančio priešingo rezultato fenomenas, konstruktyvistinè metodologija 